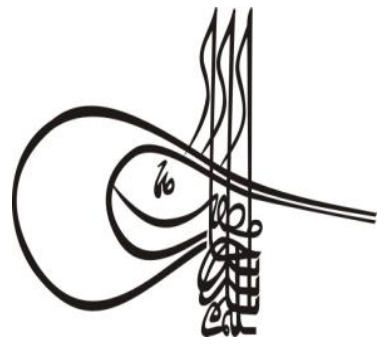

Received/Geliş: 19.08.2019

\section{Turkish Studies \\ Social Sciences}

Volume 14 Issue 5, 2019, p. 2501-2513

DOI: 10.29228/TurkishStudies.30259

ISSN: 2667-5617

Skopje/MACEDONIA-Ankara/TURKEY

Research Article / Araştırma Makalesi

ArticleInfo/MakaleBilgisi

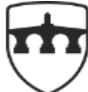

INTERNATIONAL BALKAN UNIVERSITY

EXCELLENCE FOR THE FUTURE IBU.EDU.MK

Gor Report Dates/Rapor Tarihleri: Referee 1 (20.09.2019)-Referee 2 (17.10.2019)

This article was checked by iThenticate.

\title{
VAATLER VE SLOGANLARLA MUHTARLIK YARIŞLARI: 2019 YEREL SEÇİMLERİ BROŞÜR ÇÖZÜMLEMESİ
}

\author{
Murat SEZIK*
}

\section{öz}

Muhtarlık kurumu Osmanlı'dan günümüze devrolan az sayıdaki kurumdan birisidir. Mahalle ve köyyönetimi denilince akla ilk gelen kurum olan muhtarlık ve ihtiyar heyeti günümüzde akademik ve siyasal tartışmalara konu olmakla beraber önemini korumaktadır.

Akademide ve siyaset dünyasında muhtarlara ilişkin değerlendirmeler kendi arasında ikiye ayrılmaktadır. Bunlardan biri muhtarların merkezi idareden kaynaklanan görevlerinin, mahallelinin "e-devlet", yerel yönetimlere ilişkin görevlerinin de "e- belediye" uygulamalarıyla gerçekleştirmesinden dolayı muhtarlara artık ihtiyaç kalmadığı; diğeri ise mahallelinin merkezi yönetimlerle ve yerel yönetimlerle irtibatını sağlayan, mahallelinin taleplerini dinleyip ilgili kurumlara aktardığ 1 ve bu bağlamda vatandaş ile devletin temasını sağlayan bir ajan görevini üstlendiği için önemli bir kurum olduğu yaklaşımıdır.

Muhtarların özlük haklarının iyileştirilmesi ve Cumhurbaşkanlığı makamının muhtarlara verdiği özel önem son dönemde muhtarlığı cazip hale getirmiş ve 2019 yerel yönetim seçimlerinde muhtar adayları sayısında önemli bir artış olmuştur. Bu artış muhtarlık yarışını kızıştırarak muhtar adaylarının seçmenlerine ulaşabilecekleri çeşitli materyal arayışına itmiştir. Bu materyallerden olan aday tanıtım broşürleri adayları ve projelerini seçmenlere anlatan en önemli seçim malzemesidir.

Muhtar adayları seçim öncesinde hazırladıkları broşürlerde aday oldukları mahalle için neler yapacaklarını yazmışlar ve geliştirdikleri sloganlar ile de akılda kalarak seçmenlerden oy talep etmişlerdir. Broşürlerin incelenmesinde birçok sloganın çok iddialı olduğu, vaatlerin 
ise muhtarların görev alanından ziyade yerel yönetimlerin görev sahasına giren işler olduğu, adayın eğitim durumu, önceki mesleki birikimi ve cinsiyetinin bu slogan ve vaatlere etki ettiği görülmektedir.

Anahtar Kelimeler: Muhtar, Mahalle, Yerel seçimler, Vaatler

\title{
MUKHTAR RACES WITH PROMISES AND SLOGANS: BROCHURE ANALYSIS OF LOCAL ELECTIONS 2019
}

\begin{abstract}
Mukhtarship is one of the few institutions transferred from the Ottoman Empire to the present. Neighborhood and village administration is the first institution that comes to mind when it comes to the chairman and the council of elders are still subject to academic and political debates but they remain important.

The assessments of muhtars in academia and in the political world are divided into two.One of them is that muhtars are no longer needed because of the central administration of the muhtars, and the local e-government tasks of the local administrations through the "emunicipality" applications. the other is that it is an important institution that ensures the contact of the neighborhood with the central and local administrations, listening to the demands of the neighborhood and transferring them to the relevant institutions and acting as an agent that ensures the contact between the citizens and the state in this context.

Improving the personal rights of mukhtars and the special importance given to the mukhtars by the Presidency have recently made the mukhtar attractive and there has been a significant increase in the number of mukhtar candidates in the 2019 local government elections. This increase exacerbated the mukhtar race and led the mukhtar candidates to search for various materials to reach their voters. Candidate promotional brochures, which are among these materials, are the most important selection material explaining the candidates and their projects to the voters.

The mukhtar candidates wrote in the brochures they prepared before the elections and asked what they would do for the neighborhood they were running for and they asked the voters to vote with the slogans they developed. In the examination of the brochures, it is seen that many slogans are very ambitious and the promises are the jobs that fall within the scope of local administrations rather than the field of mukhtars.
\end{abstract}

\section{STRUCTURED ABSTRACT}

\section{Introduction}

The neighborhood is the smallest unit of local government. This unit has been in our administration system since the Ottoman Empire period and is organized as a neighborhood mukhtar. Mukhtar is the head of the mukhtar institution. While some of the duties of the muhtar 
are related to local governments, most of them are the tasks carried out on behalf of the central administration.

With the regulations introduced by the Law No. 6360, the reorganization of the status of towns and villages as neighborhoods in the metropolitan cities resulted in the increase of the importance of the mukhtar and the mukhtarship institution. As a result, the number of candidates for the mukhtar election race has increased significantly.

The fact that mukhtars are candidates for themselves, not as candidates of any political party, leads the independent headmen to evaluate this institution and its governor independent of political influences, while the mukhtars are independent of the parties and intra-party discipline.

\section{Aim and Method of Research}

This research focuses on the selection of village headmen and elderly councils in the 31 March 2019 local elections. The universe of the research is the city of Malatya. The main axis of the study is the selection brochures used by the mukhtar candidates during the preelection process in different districts of Malatya. In the brochures, evaluations were made on mukhtar candidates' understanding of muhtarship, the slogans used, the political approach pointed out by these slogans, the services they plan to bring to the neighborhood, promises, promises and the like. It is also tried to explain how mukhtar candidates see mukhtar as a management institution by reading these brochures.

In this research, articles about the mukhtar institution and mukhtars were evaluated and literature research, books and electronic data were also used to enrich the research, but the main topic of the study was developed through brochures distributed by the Malatya neighborhood mukhtars in the neighborhoods. The aim of this research is to analyze the slogans and promises used in the brochures that the mukhtar candidates summarize their works and introduce themselves to the neighborhood. As a result of this, how much of the promises given to the muhtar is in the field of duty, to what extent the slogan of the mukhtar candidate who does not participate in the election on behalf of any political party is similar to the political party slogans, the relation of the mukhtar candidate with the service concept or the relationship with the profession and similar situations will be evaluated.

\section{Discussion}

The research was conducted on the brochures of 35 village headmen candidates. Although the number of muhtar candidates is far beyond these figures, the ones that can be accessed through the brochures were evaluated. 3 of these candidates are women and others

are men. This situation is reflected in the promises and slogans of the mukhtar candidates in the neighborhoods of Malatya, which have no problem in terms of access to urban services, have social reinforcement areas and adequately received local services. For example, in the brochures prepared by the mukhtar candidates, social organizations took place instead of the local service titles planned to be made. For example, the service concept that has come to the forefront 
in these neighborhoods has been to create social facilities and to bring young people to sports.

In the neighborhoods which are problematic in terms of access to urban services and where poverty is high, the candidates' promises on eliminating the poverty of the neighborhood and accessing urban services are prioritized. . For example; transportation (Intersection arrangement), Lighting (street and street lighting completion), Security (Mobese system), Bread buffet (MEGSAŞ Buffet), Sports Complex, Social Assistance Fund (with the support of SYDV and City Administration) and transportation of natural gas to the whole neighborhood has been brought to the fore as the elimination of the lack of places of worship.

\section{Conclusion}

While mukhtars define themselves as managers and leaders of the neighborhood, they emphasize that the duty of the mukhtars should not be thought of merely as issuing documents. According to the brochures prepared according to the mukhtar candidates; Mukhtar is the person who knows the problems of the neighborhood. Who is poor in the neighborhood, who is in need of help knows the best muhtar. In addition, municipalities, districts with a large number of districts in which there is a problem in the asphalt of the street, which sidewalks, which street lamp does not work, trees pruned regularly, clogged sewer lines, drinking water lines, etc. can not follow them one by one. The headman of the neighborhood is the one who knows them best. It is important that a muhtar who properly conveys the problems of his neighborhood to the relevant places has fulfilled his duty properly.

The importance given by the Presidency to the mukhtarship institution and mukhtars both encouraged the mukhtar candidates and increased the popularity of the mukhtarship. As a result of these meetings, the capacity of muhtars, especially in the local administrations, has increased, and this has significantly increased their employment rates. In addition, improvements in the personal rights of mukhtars have led to significant increases in the number of mukhtar candidates in mukhtar elections.

Today, the most important duties of the mukhtars are to follow the responsibilities given to the local administrations, metropolitan municipalities, municipalities and special provincial administrations by various laws. However, all the mukhtar candidates, especially those who wish to be elected in the new term, who were the mukhtar in the previous period, play a role from the local administrations in their neighborhoods and write the local services provided by the local administrations to their households.

Female mukhtar candidates increased incomparably compared to previous periods. It can be concluded from this point that women in the local community are more willing to participate in political processes than in previous periods. The language used by women candidates in their election studies was reflected in the brochures with the words "justice, growth of children in healthy environments, peace, cooperation" and female candidates were separated from male candidates with these aspects.

Keywords: Mukhtar, Neighborhood, Local Elections, Promises 


\section{Giriş}

Yerel yönetimin en küçük birimi olan mahallede, yerel hizmetler ve merkezi hizmetlerin yürütülebilmesi için muhtarlık birimi oluşturulmuştur. Mahallenin yönetiminden sorumlu olan muhtarlı̆̆ın, Osmanlı dönemindevar olan, cumhuriyet yönetiminde de varlığını devam ettirensiyasi, yönetsel ve toplumsal ihtiyaçların sonucu oluşan bir kurum olmasıonun tarihsel kökleri olan önemli bir kurum olduğunu göstermektedir.

Mahalle ve muhtarlık Osmanlı'da yeni kurulan belediye yönetimlerinin ülke topraklarına yerleşmesinde önemli aktörlerden biri olmuş, belediye kente üst ölçekten bakarken mahalle ölçeğinde belediyeninen önemli çözüm ortağı muhtarlık olmuştur. Muhtarları yönetsel ve siyasal açılardan güçlendiren yönseçimle iş başına gelen bir aktör olmaları ve mahalleliyle doğrudan iletişim kurmalarıdır.

Muhtarlık kurumunun görevlerinin çoğu, merkezi idare adına yürütülen görevlerdir. Bunun böyle olması, muhtarları bir yandan merkezi idare hiyerarşisine tabi vali ve kaymakamlara bağlı memurlar olarak görülmesine yol açarken, öte yandan seçimle işbaşına gelen organları ve yerel halkla sürekli iletişim halinde olması anayasa açısından olmasa da mahalli idare birimi niteliğinde görülmesine yol açmaktadır.

6360sayılı yasanın getirdiği düzenlemeler ile büyükșehir olan illerde beldelerin veköylerin statüsünün mahalle olarak yeniden düzenlenmesi, mahalle yöneticisi olan muhtarın önemini artırmıştır. Ayrıca, muhtarların özlük haklarında meydana getirilen birtakım düzenlemeler, belediyelerde muhtarlara ilişkin müdürlük veya daire başkanlıklarının kurulması, Cumhurbaşkanlık Makamının muhtarlara gösterdiği yakın ilgi muhtarlık yarışına katılan insan sayısınıartırmıştır. Bunlar dışında muhtarların herhangi bir siyasal partinin adayı olarak değil de kendi başlarına aday olmalarına, mahallede yaşayanlar açısından ise bu kurumu ve yöneticisini siyasal etkilerden bağımsız değerlendirmelerine neden olmuştur. Bu durum muhtar adaylarınınrahat hareket etmesi ve mahalleleri için muhtarlık yarışına özgür iradeleri ve bireysel değerlendirmeleri neticesinde katılmalarını sağlamıştır.

$\mathrm{Bu}$ araştırma 31 Mart 2019 yerel seçimlerinde gerçekleştirilen mahalle muhtarlıkları ve ihtiyar heyetleri seçimi üzerine odaklanmıştır. Araştırma evreni Malatya ilidir. Muhtar adaylarının seçim öncesi süreçte Malatya'nın farklı mahallelerinde yürüttükleri seçim çalışmalarında kullandıkları seçim broşürleri çalışmanın ana eksenini oluşturmaktadır. Araştırmanın amacı mahalli idare seçimlerinde seçimleri kazanmak isteyen muhtar adaylarının hazırladıkları broşürlere yansıyan muhtarlık anlayışı, kullanılan sloganlar, bu sloganların işaret ettiği siyasal yaklaşım, mahalleye getirmeyi planladığı hizmetler, vaatler, verilen sözlerve benzerleri üzerinden değerlendirmeler yaparak, muhtar adaylarının muhtarlığı nasıl bir yönetim kurumu olarak gördüğünün anlaşılmasıdır.

\section{Muhtarlık Kurumu ve Tarihçesi}

Muhtarile ilgili tanımların ortak özelliği "köy ya da mahallenin yasalarla belirtilmiş işlerini yürütmek üzere, o köyde ya da mahallede oturanlarca seçim yoluyla göreve getirilmiş kimse" şeklindedir. Türkiye'de muhtar çoğunlukla siyasal kimliği ön plana çıkarılan, iktidar ile işbirliği içinde ve fakat kendi menfaatlerini ön plana alan bir kişilik olarakedebiyatta, sinemada sıklıkla işlenmiş tarihi ve kültürel yönleri olan önemli bir figürdür. Mahalle Muhtarlığı Osmanlıdan Türkiye Cumhuriyetine aktarılan ve sadece Osmanlı'nın egemenliği altındaki topraklarda var olan bir kurumdur. Osmanlı Döneminde 19. yüzyılın başında, İstanbul'da Fatih semtinde oturan Türk-Müslüman ahalinin Sultandan izin almadan kendi başlarına oluşturdukları bir kurumdur. Daha sonraları II. Mahmut zamanında 1829'da çıkarılan bir kanunla, muhtarlık resmiyet kazanmıştır (Ercoşkun, 2012.133).

Muhtarlık teşkilatının kurulmasından önce Osmanlıda mahallenin, köyün veya kasabanın ileri gelen kişisi anlamına gelen muhtar, (Güneş, 2009: 3) mahallelinin ve köylünün devlete ve onun

\section{Turkish Studies - Social Sciences}

Volume 14 Issue 5, 2019 
temsilcilerine ulaşma vasıtası olarak anlaşıldığı gibi, yeri geldiğinde köyde devleti ve onun otoritesini de temsil etmiştir (Gül vb. 2104: 227).

Muhtarlık teşkilâtı 1829'da İstanbul'da ve bilâd-1 selâsede (Üsküdar, Galata ve Eyüp) İstanbul'a göçü kontrol etmek amacıyla uygulamaya konulmuş ayrıcamahallelere giriş çıkışı denetim altına almak, mahalle güvenliğini sağlamak ve yönetim aleyhinde yapılan dedikoduları önlemek gibi birtakım amaçlar da güdülmüştür. Bu düzenleme ile daha önce muhtarlık görevini yürüten imamların mahalle içindeki rolü ikinci dereceye düşmüştür. Bu durumu mahallede sekülerleşme başlangıcı olarak görmek mümkündür. Muhtarlık teşkilâtı İstanbul dışında 1833'ten itibaren önce Kastamonu'da oluşturulmuştur. Kastamonu sancağına bağlı Taşköprü’de âyan Hacı Ömer'in halka kötü davranması ve fazla vergi toplaması üzerine ortadan kaldırılmasının ardından mütesellim Mustafa Ağa, onun yerine yeni âyan seçtirmeyerek İstanbul'da uygulanmakta olan muhtarlık usulünü getirmiştir (Akyıld1z, 2006:53).

1871'de yaygınlaştırılan sisteme göre Müslümanlar ve gayrimüslim cemaatler beraber yaşadıkları köylerde kendi muhtarlarını bir yıllı̆̆ına seçmeye başladılar. Muhtarlık seçimlerinde Osmanlı uyruğunda olan ve 18 yaşını doldurmuş erkekler arasından yılda en az elli kuruş vergi verenler katılabiliyordu. Muhtar olabilmek için de belli miktar vergi ödemek zorunluluğu vard1 (Bardakçı, 2015).

Mahalle muhtarı ve ihtiyar heyetleri, 1913 tarihli İdare-i Umumiye-i Vilayet Kanunu ile kaldırılmış olduğu halde, varlıklarını mahallelerdeki kamu hizmetlerinin bir gereği olarak 1933 yılına kadar fiilen sürdürmüşlerdir. Bu tarihte çıkartılan 2295 sayılı kanunla varlığ 1 sona erdirilen kuruluşun görevlerini, zabıta ve belediye gibi bazı kuruluşların yapması öngörülmüştür. Ancak 10 yıllık bir uygulama mahalle muhtarlı̆̆ının boşluğunun doldurulmasının mümkün olmadığı görüldüğünden, 1944 tarihli ve 4541 sayılı Şehir ve Kasabalarda Mahalle Muhtar ve İhtiyar Heyetlerinin Teşkiline Dair Kanun ile Kanunun uygulama şekil ve esaslarına dair 1945 tarihli tüzük çıkarılmıştır ve bugünkü şeklini almıştır. Günümüzde varlığını koruyan ve muhtarlık mahalle yönetimini düzenleyen yasa 05.04.2004 tarihinde Bakanlar Kurulu Kararı ile kabul edilmiştir. Türkiye'de yaklaşık olarak 53 bin adet muhtarlığın 36 bini köy, 17 bini ise mahalle muhtarlığıdır. Günümüzde muhtarlar belediye başkanlarıyla aynı anda ve aynı süreyle 5 yıllığına seçilmektedir.

\section{Mahalle Ve Köy Muhtarlarının Görevleri}

Mahalle muhtar ve ihtiyar kurullarının nasıl oluşacağı ve görevleri "Şehir ve Kasabalardaki mahalle Muhtar ve İhtiyar kurulları Tüzüğ̈̈"ndebelirtilmiştir. Tüzüğün 4. maddesi mahalle muhtar ve ihtiyar kurulununbir muhtar ile dört asil üye, dört yedek üyedenoluşacağını belirtmiş, muhtar ve ihtiyar kurullarının görevleri ise 32. maddede sayılmıştır.

Buna göre muhtarın Nüfus Kanunu, 111 Sayılı Askerlik Kanunu,1525 sayılı Şose ve Köprüler Kanunu, 1086 sayılı Hukuk Usulü Muhakemeleri Kanunu,1412 sayılı Ceza Muhakemeleri Usulü Kanunu, 797 sayılı Veraset ve İntikal Vergisi Kanunu,393 sayılı Muzır hayvanların itlafı hakkındaki Kanun,1580 sayılı Belediye Kanunu,2644 sayılı Tapu Kanunu, 1593 sayılı Umumi Hifzissihha Kanunu,1918 sayılı Kaçakçılığın men ve takibine Dair Kanun gibi çok fazla sayıda kanunda zikredilen görevleri bulunmaktadır. Bunlardışındayardıma muhtaç olanlara fakirlik ihtiyaç ilmühaberlerini vermek, mahallede oturanlar hakkında resmi kurumlar tarafından istenilen iyi hal kağıtlarını yazmak ve konut senedini onama, mahallede oturanlarla yakından ilgilenerek mahalleye girdiğini haber aldığ hüviyeti belirsizve şüpheli kimseler hakkında kolluğa haber vermek gibi görevleri bulunmaktadır.

$\mathrm{Bu}$ görevleri yerine getirmek durumunda olan muhtar ve ihtiyar heyetinin çalışma şekli ise 40. maddeden itibaren düzenlenmiştir. buna göre; " Ihtiyar kurulu asli üyeleri haftada en az iki defa belli saatlerde muhtarın çalışma yerinde toplanmak ödevindedirler." Bu saatlerin dışında muhtarın çağrısı üzerine detoplanılacağı ifade edilen tüzükte muhtar ve ihtiyar kurulu üyeleri, görevlerini günü gününe görürler ve herhangi makbul sebep olmadıkça halkın işlerini hiçbir suretle bir günden fazla

\section{Turkish Studies - Social Sciences}

Volume 14 Issue 5, 2019 
alıkoyamazlar ifadesi ile işlerin hızlı bir şekilde görülmesi hedeflenmiştir. Mahallelinin işlerinin aksamaması adına muhtarlar, herhangi zaruri bir sebeple geçici olarak görevlerinden ayrılmak istediklerinde en büyük mülki amire bilgi vererek, yerlerine ihtiyar kurulu üyelerinden birini vekil bırakabilecekleri de düzenlenmiştir.

442 Say11 Köy KanunundaKöy muhtarı ve ihtiyar meclisi heyetinin seçilme koşulları vegörevleri tanımlanmıştır. Bunlardan ilki "Köyün sınırı içinde köylüye ait işleri yapmak ve yaptırmak muhtarla onun başında bulunduğu ihtiyar meclisinin vazifesidir." şeklinde ifade edilmiştir. Zira köy kanunu köyde yapılacak işleri iki başlık altında ele almıştır. Kanunun ikinci faslında köye ait işler başlığı altında mecburi olan işler ve isteğe bağlı işler ayrımı bu anlamda önemlidir. Muhtar için ayrıca "muhtarın göreceği işler" başlığı 35. maddede düzenlenmiştir. Bunlar da kendi arasında devlet işleri ve köy işleri şeklinde bir ayrıma tabi tutulmuşlardır.Devlet işleri olarak sayılan görevler mahalle muhtarlarında olduğu gibi merkezi yönetimin iş ve işlemleri yanında birtakım kolluk görevleridir. Köy işleri olarak sayllan görevler ise köye ilişkin her türlü yerel hizmet ve köyün mali işleridir.

Muhtarlara verilen görevler ve yetkiler bağlamında konuyu ele aldığımızda köy muhtarının ve ihtiyar heyetinin mahalle muhtarına göre köy kanunundan kaynaklanan birtakım yetkiler ile donatıldığı söylenebilir. Örneğin 35. maddede "Köy muhtarına köy işlerini gördükleri zaman karş1 gelen ve kötü söyleyenler devlet memuruna karşı koyanlar gibi ceza görürler" denilerek koruma altına alınmıştır.40. maddede geçen "Köy muhtarının köylü faydasına olmayan kararlarını kaymakam bozabilir. Fakat, onun yerine kaymakam kendiliğinden karar veremez. Karar, gene köylü tarafından verilir." değerlendirmesi de köylünün yerine mülki idare amirinin işlem tesis edememesi anlamına gelmektedir.

Yerel yönetim yapılanması açısından konu ele alındığında ise mahalle yönetiminin köy yönetiminden farklı olarak yerel yönetim kuruluşu olmadığı ifade edilmelidir. Mahalle muhtarlığı merkezi ve yerel idarenin şehir ve kasabaların mahallelerinde bulunan mümessilliğidir. Yerel yönetimler il, belediye ve köy halkının mahalli müşterek ihtiyaçlarını karşılamak üzere kanunla kurulan kamu tüzel kişileridir. 1982 Anayasasının 127. maddesine göre yerel yönetimler il özel idaresi, belediye ve köyden oluşmaktadır (Koçberber, 2005: 105).

6360say1lı yasa ile büyükşehir olan illerde köyler mahallelere dönüştürülmüş böylece gündeme "kırsal mahalle" kavramı girmiştir. Cumhurbaşkanlığı makamının muhtarlık müessesesine verdiği önem ve yukarıda ifade edilen yasal düzenlememuhtar-belediye ilişkilerinde değişiklikleri de beraberinde getirmiştir. Özellikle kırsal mahallelerde, belediye ile muhtarlıklar arasındaki ilişkiler artmış, kırsal mahalle muhtarlıkları, idari ve mali nitelikli yetkileri olmadığı için, köydeki büyük ve küçük nitelikteki her türlü ihtiyacı için belediyelere bağımlı olmuşladır. Söz konusu muhtarlar talep, şikâyet ve önerilerini, ilçenin uzak noktalarından belediyelere iletmek zorunda kalmıştır (Argüden vd., 2018: 32). Bu durum kırsal mahallenin işlerini takip eden muhtarların önemini artırmıştır. Girişken, liderlik özellikleri olan, siyasilerle iyi geçinen, iletişim becerileri yüksek muhtar adaylarına duyulan ihtiyaç artmıştır.

\section{Mahalle Muhtarlarının Tanımlanmamış Görevleri}

Muhtar mahallenin yöneticisi olarak mahalleyi ilgilendiren konularda başta belediyeler olmak üzere her türlü kamu kurumuna başvurabilir, bilgi isteyebilir. Muhtar, mahalle adına ve mahallede yaşayan insanlar adına hak aramak, söz söylemek, görüş ve öneride bulunma haklarına sahiptir. $\mathrm{Bu}$ hak, muhtar ve ihtiyar heyetininhalk tarafindan doğrudan seçilmiş olmasından kaynaklanmaktadır. Ayrıca yurttaşlar da her zaman kamu işleri konusunda görüşte bulunup, kamunun bazı şeyleri yapmasını ya da yapmamasını isteyebilir.

Muhtarın mahalle halkının temsilcisi olarakonların bireysel veyatopluluğu ilgilendiren sorun ve şikâyetleri konusunda yasal olarak tanımlanmamış olsa da"yerel kamu denetçisi- mahalle ombudsmanı" rolü de bulunmaktadır. Bu konuda muhtar, mahalle halkından hak arayan herkese yol 
gösterebilir, yardımcı olabilir. Bu bir kamu görevlisi veya kamu kurumundan şikâyetçi olma konusu olabileceği gibierişemediği bir kamu hizmetine ulaşma isteği de olabilir. Muhtar hizmete ulaşmak isteyen mahalleliyeyol göstermeyi, devletten veya belediyeden sosyal yardım talep etmeyi de içeren fakat yasal düzenlemelerde göremediğimiz birtakım görevleri de ifa etmektedir.

Ayrıca muhtar mahallesindeki veya köyündekikavgaları, sorunları çözmede önemli roller üstlenebilmektedir. Bu yönü ile muhtar bir kanaat önderidir. Zira kanaat önderleri halkın dertleriyle hemhal olmuş, halkın aşina olduğu kişilerden oluşmaktadır.

Kanaat önderi olarak muhtarlar, ilişkilerin daha yakın, yüz yüze devam ettiği yerlerde daha çok uyumlaştırıcı rollere sahiptirler. Çeşitli vakalarda ara bulma, önemli günlerde "önde gitme" anlamında toplumun bir bakıma vitrininde yer almaktadırlar. Bu uyumlaştırıcı liderler genellikle çözüm insanı olarak rol oynamaktadırlar. Özellikle mahalle ve köy gibi küçük yerleşim yerlerinde bu farkı görmek oldukça kolay olmaktadır. Küçük yerleşimlerde insan ilişkileri daha yakın, duygular daha perdesiz olarak yaşanmakta ve paylaşılmaktadır. En küçük bir geçimsizlik ve yaramazlıkta özellikle başvurulan ve olayın içinde olması arzu edilen tipler vardır. Örneğin köyün yaşlıları, imam, muhtar, okul müdürü ve öğretmenler, eğitim almış kişiler, çözümün ve uyumun sağlayıcısı olarak görülmektedirler (Ulutaş,2019: 36).

Muhtarlık, hem merkezi, hem de yerel yönetimin bir parçası olmakla birlikte aynı zamanda da bu yönetimlere karşı, mahalle halkının bir temsilcisi olarak görev üstlenen yarı sivil-yarı resmi demokratik bir kurumdur. Muhtarlığın bütçesi yoktur, hukuki özerkliği de sınırlıdır.

\section{Muhtarların Özlük Hakları}

5 yılda bir seçimle iş başına gelen ve partilerden bağımsız olarak görev yapan köy ve mahalle muhtarlarının özlük haklarına ilişkin en önemli düzenleme "Muhtar Ödenek ve Sosyal Güvenlik Kanumunda Değişiklik Yapllmast Hakkanda Kanun Teklifi'ile gündeme gelmiş̧ir.

Kanun teklifinde muhtarların, yetki alanına giren konularla ile ilgili masraflarını kendi maaşlarından karşılayarak görevlerini yerine getirmeye çalıştı̆̆ muhtar maaşı ile geçindiği ifade edilerek muhtarlarınsosyal güvenlik primlerini de bu maaştan karşılamaya çalıştıkları vurgulanmıştır. Ayrıca görevlerini yerine getirmeye çalışan muhtarların, çağın gereksimi olan araç ve gereçleri de kendi imkanları ile sağlamak durumunda kaldıkları, muhtarlık bürolarının zaruri ihtiyaçlarını karşılamak da da zorlandıklarıbelirtilerek, sosyal ve ekonomik haklar bakımından mağduriyetlerinin bir an önce giderilmesi kanun teklifinin üzerinde durduğu konu olmuştur.

Teklifi hazırlayan Cumhuriyet Halk Partisi Milletvekilleri kanun teklif metnin gerekçesinde muhtarlık hizmet binalarının elektrik, su, telefon, doğalgaz, internet vb. giderlerinin hizmetle bağdaşır kısmı İçişleri Bakanlığı bütçesinden karşılanması, muhtarların sosyal güvenlik primlerinin de devlet tarafından karşılanması öngörülmüştür (Özel, 2015)

Kanun teklifinin ülke gündemine girmesinden sonra6663 Sayılı "Gelir Vergisi Kanunu İle Bazı Kanunlarda Değişiklik Yapılmasına Dair Kanun" 12. maddesinde özlük haklarının düzeltilmesine yönelik ilk adım atılmış, 5147 sayılı Muhtar Ödenek ve Sosyal Güvenlik Yasasında ilk önemli değişiklik 29.01.2016 tarihinde gerçekleştirilmiştir. Buna göre "Köy muhtarları ile şehir ve kasaba mahalle muhtarlarına, 14.750 gösterge rakamının memur aylık katsayısı ile çarpımı sonucu bulunacak miktarda aylık ödenek verilir." denilerek aylık ödemelerde iyileştirme gerçekleştirilmiştir. Diğer önemli değişiklik ise bunu izlemiştir. 01.02.2018 de 7077 sayılı kanunun 29. maddesi Köy muhtarları ile şehir ve kasaba mahalle muhtarlarınaprime esas kazanç alt sınırı üzerinden hesaplanacak sosyal güvenlik primleri, il özel idareleri veya yatırım izleme ve koordinasyon başkanlıkları tarafından doğrudan Sosyal Güvenlik Kurumuna ödenir. Sosyal güvenlik primlerinin karşıllğı her yıl İçişleri 
Bakanlığı bütçesine konulur ve yılı içinde söz konusu bütçeden il özel idare ve yatırım izleme ve koordinasyon başkanlıkları bütçelerine aktarılır şeklinde düzenlenmiştir.

\section{Araştırmanın Amacı ve Yöntemi}

$\mathrm{Bu}$ araştırmanın amacı muhtar adaylarının yapacakları işleri özetledikleri ve kendilerini mahalleliye tanıttıkları broşürlerde kullandıkları sloganlar, vaatler üzerindençözümleme yapmaktır. Bunun neticesinde verilen vaatlerin ne kadarının muhtarın görev sahasında olduğu, siyasal açıdan herhangi bir siyasal parti adına seçime katılmayan muhtar adayının sloganının siyasal parti sloganları ile ne ölçüde benzeştiği, muhtar adayının hizmet anlayışı ile yürütmekte olduğu veya emekli olduğu meslek ile ilişkisi ve benzeri durumlar değerlendirilecektir.

$\mathrm{Bu}$ araştırmada daha önceden muhtarlık kurumu ve muhtarlar üzerine ortaya konulan makaleler değerlendirilmiş ve literatür taraması, kitap, elektronik verilerle araştırma zenginleştirilmeye çalışılmış, fakat çalışmanın ana omurgasını oluşturan konu Malatya mahalle muhtar adaylarının seçim bölgeleri olan mahallelerde dağıttıkları broşürler üzerinden geliştirilmiştir.

Nitel araştırma yöntemlerinden olan sahadan verilerin toplanmasına mahalli idare seçimlerinden bir ay öncebaşlanılmış ve saha verileri ile birlikte yapılandırılmamış gözlem ile araştırma şekillendirilmiştir. Neuman'ın ifadesi ile "Saha araştırması arzu edilen bilgileri edinmek ve bu bilgiler hakkında düşünme süreçleri için her türlü tekniğin kullanılabileceği bir şemsiye gibidir. Saha araştırmacısı, doğal toplumsal ortamlardaki anlamları inceler ve çok sayıda bakış açısını kavrar. Üyelerin anlam sisteminin içine girer ve sonra araştırmanın dışarıdan bakış açısına geri döner" ( 2013: 548) yaklaşımı veBüyüköztürk' ün " yapılandırılmamış gözlem, araştırmacıya bilgi toplamada ve kayıt etmede özgürlük sağlayan bir tür yöntem" (2018:146 )yaklaşımları bu araştırmanın yönteminin belirlenmesinde etkili olmuştur.

\section{Araştırmanın Kapsamı ve Örneklemi}

Araştırmanın kapsamı mahalle muhtarları ile sınırlı tutulmuştur. Bunun temel gerekçelerinden biri 6360 sayılı yasal düzenleme ile büyükşsehir olan illerde köylerin kaldırılarak mahalleye dönüştürülmüş olmasıdır. Bu bağlamda araştırmanın evreni Türkiye'dir. Bu çalışmada öncelikle uygun örneklem yöntemiyle Malatya kent merkezi seçilmiş ve araştırma 35 mahalle muhtar adayının broşürleri üzerinden yürütülmüştür.

Muhtar aday sayısı bu rakamların çok ötesinde olmakla beraber çalışmada tanıtım broşürlerine ulaşılabilenler değerlendirmeye alınmıştır. Bu adaylardan 3 tanesi kadın diğerleri erkektir. Araştırma Malatya'nın Çilesiz Mahallesi (6), Cevatpaşa Mahallesi (2), Yavuz Selim Mahallesi (5), Özalper Mahallesi (2), Göztepe Mahallesi (2), Frrat Mahallesi (2), Hidayet Mahallesi (2), Zaviye Mahallesi (6), Çöşnük Mahallesi (2), Hacı Abdi Mahallesi (4) ve Uçbağlar Mahallesi (2) muhtar adaylarının seçim çalışmalarında kullandıkları broşürler üzerinden yürütülmüştür.

\section{Araştırmanın Bulguları}

Malatya'nın çok hızlı değişen ve yapılaşan mahallelerinden biri Çilesiz mahallesidir. $\mathrm{Bu}$ mahalle Malatya'nın birçok mahallesinde bulunmayan sosyal donatı alanlarına sahip, yerel hizmetleri almışörnek mahallelerdendir. Bu durum muhtar adaylarının vaatlerine ve sloganlarına da yansımış durumda. Örneğin muhtar adaylarının hazırladıkları broșürlerde yapılması planlanan yerel hizmet başlıkları yerine daha farklı temalar işlenmiştir. Bayan adaylardan biri "Çalışkan, Samimi, Adil" ifadelerinin ön plana çıkarırken daha küçük puntolarla " Evli ve3 çocuk annesiyim, 38 yaşındayım, Üniversite mezunuyum, Toplumsal Hayatta En Önemli iş iyilik, en önemli görev hoşgörüdür. Bu ilkeyle tüm mahalle sakinleriyle uzun ve güzel bir yol alacağıma inanıyorum"yaklaşımı içerisinde mahalleliye mesajlarını iletmiştir. Aday bu ifadeler üniversite eğitimi almış bir kadın ve anne olmasının yanı sıra iyilik ve hoşgörü merkezli bir yaklaşımı benimsemiştir. 
Diğer iki muhtar adayı, muhtarın kim olduğu sorusunu sorarak cevaplar vermiştir. Örneğin; "muhtar, başınız dara düştüğünde kapısını çaldığınız ilk kişidir" yaklaşımını benimserken bir diğer muhtar adayı " Muhtar ölünüzle, dirinizle, dügününüzle derneğinizle, yolunuzla kaldırıminızla, çöpünüzle asfaltınızla, yanmayan sokak lambanızla, yani sizin her şeyinizle ilgilenen tek devlet kurumudur." ifadeleri ile muhtarın yasalarla belirlenmiş görevleri dışında birtakım görevleri olduğunu tasdik etmiştir. Hatta "Avukatlık işi olan da, doktorluk işi olan da eşiyle kavga eden de, kızı kaçan da hep muhtara koşar" yaklaşımı muhtarın bir kanaat önderi olarak görülmesinin neticesidir.

Muhtar adaylarının kullandığı sloganlar içerisinde çok iddialı olanlar da var. Örneğin, "Aydınlık yarınlar için, halka hizmet için oylarınıza talibim" cümleleri siyasal partilerin dahi çok kolaykuramadığ 1 bir cümledir.

Cevatpaşa Mahallesi kadın muhtar adayı slogan olarak "Güçlü kadın,Güçlü Gelecek" cümlesini benimsemiş ve broşürün devamında " ...Muhtar seçilmem durumunda Kamu kurumlarında ve belediyebaşkanlı̆̆ Hizmet Birimlerinden mahallemizin alması gereken hizmetleri alabilmesi için her türlü platformda mahallemizin haklarını savunacağım" ifadelerini kullanmıştır. Diğer aday ise "Hizmet İçin her zaman buradayım" yaklaşımını yeterli görmüştür.

Malatya'nın kentsel hizmete ulaşım açısından sorunlu mahallelerinden biri olan Yavuz Selim mahallesi aynı zamanda kent yoksulluğu içerisinde yaşayan ailelerinde yoğun olarak ikamet ettiği mahallelerdendir. Bu mahalledeki muhtar adaylarının gündeminde doğal olarak mahallenin yoksulluğu ve hizmetlerden yoksun kalması ön planda tutulmuştur.

Yavuz Selim Mahallesi muhtar adayları yaptıkları aday tanıtım çalışmalarında kullandıkları sloganlar incelendiğinde"Sorunları da biliyoruz çözümü de" , "teşhis tedavinin yarısıdır", "hizmet için her zaman hazırım", "mahallemizi birlikte yönetelim", "halkın derdini dinleyip hizmet için varım" ifadeleri görülmektedir. Emekli polis memuru muhtar adayı hazırladığı broşürde " görevi ve hizmeti iyi bilirim, TOKI yüklenici firmalar evleri zamaninda teslim etmediğinde dava ederek kazandım, TOKI genel yönetimini fes edeceğim" yaklaşımı ile TOKİ 'de ikamet eden mahalleliye hitap etmiştir.

Seçim döneminde muhtar olan ve muhtarlığa devam etmek isteyen adayın mahalleye gelen hizmetler için "muhtarlığımızın getirmiş olduğu hizmetler" başlığını kullanarak 52 farklı hizmet çeşidini gündem yapması muhtarların hizmet anlayışını ortaya koyması açısından önemlidir.Muhtarlar tarafından talep ve takip edilen işlerin önemli bir kısmı yerel yönetimlerin alanına giren işler olmakla beraber merkezi yönetimin görev alanına giren işlerin de bulunduğu daha önceki sayfalarda ifade edilmişti. Muhtar adayının bu iş ve işlemleri ilgili kurum ve kuruluştan doğru bir şekilde talep ediyor olmasi bu hizmetleri yerine getirmesi anlamına gelmeyecektir fakat mahallenin sorunlarının takip edilmesi dahi muhtarı önemli çözüm ortaklarından biri haline getirmektedir. Bir diğer muhtar adayının mahallenin sorunları başlığı altında ifade ettiğikonular, ulaşım (Kavşak düzenlemesi), Aydınlatma (cadde ve sokak aydınlatmasının tamamlanması), Güvenlik (Mobese sistemi), Ekmek büfesinin açılması (MEGSAŞ Büfesi), Spor Kompleksi, Sosyal yardımlaşma fonu oluşturulması ( SYDV ve İl özel idaresi desteği ile) ve Doğalgazın bütün mahalleye ulaştırılması, ibadethane eksikliğinin giderilmesi olarak ön plana çıkarılmıştır.

Özalper mahallesindeki bir muhtar adayı hazırlanan broşürden anlaşıldığı kadarıyla seçim döneminde muhtarlık görevini üstlenenmiş durumda. Slogan olarak "Durmak YokHizmete Devam" ve "Sizlerle Hep Birlikte" cümlelerini belirlemiştir. Hazırlanan broşürdeYaptıklarımız (Kısaca) ve hedeflerimiz (yapacaklarımız) başlıkları altında Selçuklu ve Osmanlımimarisine uygun Özalper İlkokulu ve Abdulhamit Ortaokulunun yapılmasında vesile olunduğu, Semt konağı ve muhtar evinin yapılmasına da katkılar verildiği ifade edilmiştir. Bunlar dışında mahallede her türlü etnik, yöresel, kültürel ayrımcılığa son vererek, milli birlik ve beraberliğin korunduğu vurgulanmıştır. Adilhizmet anlayışı ile yola devam edileceği ve görev süresi içerisinde hiçbir mahalleliden imza ve mühür parası alınmadığı ayrıca belirtilmiştir. 25000 nüfusa sahip bir mahalle olan Özalper'de bin kişilik çok amaçlı 
toplantı salonu yaptırılması, çocuk ve gençlerin spor yapabileceği alanların oluşturulması, Özalper Mahallesi Spor Kulübü'nün kurulması, mahallelik ve komşuluk kültürünün gelişmesi için Özalper Mahallesi Yardımlaşma Geliştirme, Kültür ve Yaşatma derneğinin kurulması, engelli bireyler için engelsiz bir mahalle oluşturma bilinci ve fiziki altyapı çalışması yapılması gibi hedefler de yapılacaklar arasında sayılmıştır. Özalper mahallesindeki diğer muhtar adayı ise mahallenin en genç muhtar adayı olduğunu ifade eden cümlelere ek olarak "Oy Sizden takdir Allah'tan" yaklaşımını yeterli görmüştür.

Malatya'nın gelişim potansiyeli taşıyan fakat yerel hizmetlerden yeterince yararlanamayan mahallelerinden olanGöztepe mahallesi muhtar adayları seçim için herhangi bir slogan belirlemek yerinebroşürde özgeçmişlerini vererek kendilerini mahalleliye tanıtmak istemişlerdir. Her iki aday da mahalle için muhtar evi, semt konağı ve taziye evi yapımını vaat olarak sunarken adaylardan biri Büyükşehir belediyesinde çalışmış olmasını özellikle ön plana çıkarmıştır.

Firat mahallesi Malatya'nın en eski, planlı ve yerel hizmetleri alan mahallelerindendir. $\mathrm{Bu}$ nedenle önemli sorunları olmayan bir mahalle. Bu mahallede muhtar adaylarından biri " Değiş̧tirelim, önce siz sonra hepimiz" sloganı ile seçmenlere hitap ederken diğer aday özgeçmişini vererek özgeçmişin altına "evet" mührü yerleştirmekle yetinmiştir.

Hidayet mahallesi de Firat mahallesi gibi Malatya'nın en eski mahallelerinden biri fakat kentsel hizmetler bağlamında daha şanssız bir mahalle. Hidayet mahallesi muhtar adaylarından biri "Hizmet Iç̧in Millet İçin Evet" sloganını benimserken diğer aday "Destek Sizden Hizmet Bizden" sloganını benimsemiştir. Adaylardan biri Mahalle meclisi kuracağını, mahallenin imar sorunlarını bildiklerini ve bu konuda gerek belediye gerekse Çevre ve Şehircilik Bakanlığı nezdinde girişimlerde bulunulacağını, yaşlı hastaların hastane işlerinde ekip olarakyardımcı olacaklarını, mahallenin ana giriş caddelerine "Hidayet mahallesine Hoş Geldiniz yazılı tabela (Dijital de olabilir)" konulacağ 1 ve Alo Muhtarlık hattının oluşturulacağı ifade edilmiştir. Diğer aday ise üniversite sınavını kazanan mahalleli gençlere burs için gerekli çalışmaların yapılacağı, Gençlerin spor yapabilmeleri için gençlerle güç birliği yaparak semt sahası yapılacağı, Mahalle merkezinde bir camii, kültür merkezi ve meslek edindirme kurs merkezi yapılmasını sağlanacağı ifade edilmiştir.

Zaviye mahallesi de Malatya'nın en eski mahallelerinden biri olmanın yanında Malatya'da 1934 yılında temeli atılan ve 1939 yılında işletmeye açılanan Malatya Pamuklu Sanayii Müessesesi'nin (Sümerbank) ve 1939yılında açılan Malatya Sigara Fabrikası'na (TEKEL) yakın bir yerdekonumlanmış olması nedeniyle hızlı büyüyen bir mahalledir. Bu işletmeler 1980'li yıllarda başlayan özelleştirme rüzgarı ile kamunun elinden çıkması neticesinde mahalle olumsuz etkilenmiş büyüme hızı önemli oranda düşmüştür.

Zaviye Mahallesi Muhtar adaylarının kullandığı sloganlar; "Mahallemizi birlikte yönetmeye var mısınız?","Hayırlıysa Allah Nasip Etsin", "Her Zaman yanınızda içinizden Biri", "Örnek Bir mahalle İçin Çözümün Adresi Olacağım", "Söylediklerimizi Hizmete Dökeceğiz", "Hürmeti ve Hizmet Etmeyi Seviyorum" şeklindedir. Muhtar adaylarının mahalleye ilişkin yapacakları ise Mahalledeki parkın fiziki durumunun iyileştirilmesi, belediye otobüs güzergahlarının mahalle sınırlarına dahil edilmesi, mahalleye bir anaokulu ve kreş yapımı, mahallede gece bekçisinin istihdamı için gerekli işlerin yapılması, mahallede yoksul mahalleli için bir fon oluşturulması, bankaların bankamatik makinelerinin mahalleye kurulması, haftada iki gün mahalle sakinlerinin sorunlarının dinlenmesi için toplantılar yapılması gibi başlıklar ön plana çıkmaktadır. Bu sayılanlar dışında kadın adayı diğer adaylardan ayıran vaatlerşöyledir: " Kadınlara yönelik resim, takı tasarımı, kuaförlük, dikiş ve el işi kursları açmak. Elde edilen ürünlerin satışını sağlamak için kermesler düzenlemek, çocuklar için temiz bir çevre, düzenli oyun alanı, parkların düzenlenmesi ve geliştirilmesi, mahalledeki karanlık ara sokakların aydınlatılmasının sağlanması, hayvanların barınması korunması ve beslenmesine yardımcı olmak, daha temiz, daha yeşil, daha sakin mutlu insanların yaşadığı bir mahalle için çalışacağım" şeklindedir. 
Çöşnük Mahallesi'de Malatya'nın büyük ve gelişmiş mahallelerinden. Bu nedenle mahallenin çok büyük sorunları yok. Bu muhtar adaylarının seçim broşürlerinde de kendini göstermekte. Örneğin adaylardan biri "Çöşnüklü'ler oylarınıza talibim" sloganı ile mahalleliye kendi öz geçmişini anlatırken diğer aday kendisi ve aday azaların resimlerini paylaşarak oy istemiştir. Bu mahallede ön plana çıan hizmet anlayışı ise " Gençleri sporla buluşturacağız, mahalleye konuk evi ve sosyal amaçlı tesisler kurulması için hazırladığımız projeleri hayata geçireceğiz" yaklaşımı olmuştur.

Hacı Abdi Mahallesi de muhtar adaylarının yoğun olduğu bir mahalle. Buradaki muhtar adayları' da " Modern bir Şehre Yakışır Modern bir mahalle İçin Çıktık Yola"," şimdi Birleşme Zamanı", "Önceliğimiz Mahallemiz" sloganları ön plana çıkmıştır. Adaylardan biri seçim döneminde muhtarlık yapan kişi. Bu nedenle önce yaptığı işleri açıklamış sonra planladıklarını sıralamış ve fakat son cümle olarak "mahallelinin istek ve teveccühlerinedeniyle bir dönem daha aday oldum " diyerek adaylığının gerekçesini ortaya koymuştur. Bir başka aday ise, mahallede geçmiş dönemlerde 25 yıl muhtarlık yapmış olan A.Ö. nün oğlu olduğunu ifade ederek" Babamın tecrübe ve deneyimlerinden faydalanarakmahalle sakinlerimizin isteği üzerine sizlere hizmet etmek için muhtarlığa adayım " yaklaşımını benimsemiştir. Diğer adayların ise aza adaylarını ön plana çıkaran bir yaklaşım içerisinde bulunduğu ifade edilebilir.

Araştırmada ele alınan son mahalle olan Uçbağlar mahallesi de Malatya'nın eski ve düzenli yerleşim alanlarından biri. Bu nedenle kentsel hizmetler bağlamında çok fazla eksiği yok. Bu durum muhtar adaylarının vaatlerine de yansımış durumda. Ağırlıklı olarak aday tanıtımı şeklinde hazırlanan broşürlerde ön plana çıkan hizmet anlayışı sosyal tesislerin oluşturulması ve gençlerin sporla buluşturulması yönünde.

\section{Değerlendirme ve Sonuç}

Muhtarlık; kökleri çok eskilere kadargiden, mahallelinin merkezi devletle ve yerel idarelerle ilk temasını sağlayan önemli bir kurumdur. Fakat günümüzde gelişen iletişim imkanları vee-Devlet uygulamaları muhtarların özellikle merkezi hükümet adına yerine getirdiği iş ve işlemleri kolaylıkla gerçekleştirme imkanınısağlamıştır. Konu bu bağlamda değerlendirildiğinde muhtarların yerel idarelerle yürüttüğü iş ve işlemlerin ön plana çıktığı söylenebilir.

Muhtarlar kendilerini mahallenin yöneticisi ve lideri olarak tanımlarken, muhtarın görevinin de sadece ikametgah vs belge vermekten ibaret sanılmaması gerektiği üzerinde durmaktadırlar. Hazırlanan broşürlerden anlaşıldığı kadarıyla muhtar adaylarına göre; Muhtar, o mahallenin sorunlarını ve mahallede kimin yardıma muhtaç olduğunu en iyi bilen kişidir. Ayrıca belediyeler, kaymakamlar çok sayıda mahallesi olan bir ilçede hangi sokağın asfaltında sorun var, kaldırımların durumu ne, hangi sokağın lambası yanmıyor, ağaçlarının düzenli budanıp budanmadı̆̆ı, tıkanan kanalizasyon hatları, içme suyu hatları vs bunları tek tek takip edemez. Bunları en iyi bilen kişi mahallenin muhtarıdır. Mahallesinin sorunlarını ilgili yerlere hemen ileten bir muhtar görevini layıkıyla yerine getirmiştir yaklaşımı önemlidir.

Cumhurbaşkanlığının muhtarlık kurumuna ve muhtarlara verdiği önem hem muhtar adaylarını cesaretlendirmiş hem de muhtarlığın popülerliğini artırmıştır. Zira bu toplantılar sayesinde muhtarların özellikle yerel yönetimlerde etki- baskı kapasiteleri artmış bu daiş görme oranlarını önemli oranda artırmıştır. Buna ek olarak muhtarların özlük haklarındaki iyileştirmeler muhtarlık seçimlerinde muhtar adayı sayısında önemli artışlara yol açmıştır.

Günümüzde muhtarların ön plana çıkan görevleri yerel yönetimlere yani büyükşehirbelediyeleri, belediyeler ve il özel idarelerineçeşitli kanunlarla verilen sorumlulukların takip edilmesidir. Ancak ne var ki bütün muhtar adayları, özellikle de önceki dönemde muhtar olan yeni dönemde de seçilmek isteyen adaylarmahallelerinde yapacakları işler konusunda yerel yönetimlerden rol çalmakta, yerel yönetimlerin yerine getirdiği yerel nitelikteki hizmetleri kendi hanelerine yazmaktadırlar. 
Kadın muhtar adayları önceki dönemlere göre kıyaslanamayacak oranda artmıştır. Buradan yerelde kadınların siyasal süreçlere katılmada önceki dönemlere göre daha istekli oldukları sonucu çıkarılabilir. Kadın adayların seçim çalışmalarında kullandıkları dil "adalet, çocukların sağlıklı ortamlarda büyümesi, huzur, işbirliği" kelimeleri ile broşürlere yansımış ve kadın adaylar bu yönleriyle erkek adaylardan ayrılmıştır.

\section{KAYNAKÇA}

Akyıldız, Ali (2006) Muhtar, - İslam Ansiklopedisi 31. Cilt, TDV Yayınları, Ankara

Argüden Yılmaz, vd. (2018), Yerel Yönetimler Ve İyi Yönetişim, Argüden Yönetişim Akademisi Yayınları.

Bardakçı, Murat (2015),"Biz seçimlerle ilk defa 1833'te tanıştık ve 43 y1l boyunca sadece muhtar seçtik" www.haberturk.com, Erişim tarihi, 10.06.2019

Büyüköztürk, Şener vd (2018), Bilimsel Araştırma Yöntemleri, Pagem Akademi, Ankara

Ercoşkun, Tülay (2012), "Osmanlı Devleti’nde Muhtarlık Kurumunun İşleyişine İlişkin Düzenlemeler ve Gözlemler", Bilig Türk Dünyası Sosyal Bilimler Dergisi, S.60, s.131-154

Gül, Hüseyin,vd.(2014) Türkiye'de Yerel Yönetimler ve Yerel Siyaset, Detay Yayınları, Ankara.

Güneş, Mehmet (2009), Osmanlı Devleti’nde Muhtarlık Teşkilatının Kuruluşu ve Gelişimi (18291864), Marmara Üniversitesi Türkiyat Araştırmaları Enstitüsü (Yayımlanmamış Yüksek lisans Tezi), İstanbul.

Koçberber, Seyit (2005), Yeni Belediye Yasası İle Mahalle Yönetimi, Sayıştay Dergisi, s.56,ss.103-114

Özel, Özgür, (2015),Muhtar Ödenek ve Sosyal Güvenlik Kanununda Değişiklik Yapılması Hakkında Kanun Teklifi"http://www.eczozgurozel.com/muhtar-odenek-ve-sosyal-guvenlik-kanunundadegişiklik-yapılması-hakkında-kanun-teklifi/ Erişim Tarihi 01.07.2018

Neuman, W. Lawrance (2013), Toplumsal Araştırma Yöntemleri, Yayan odası Yayınları: Ankara

Ulutaş, Ejder (2019), Toplumsal Değişim, İnsan ve Medeniyet Hareketi dergisi S.1(1), ss.25-45 